\title{
PENGARUH PENDEKATAN SAINTIFIK TERHADAP KEMAMPUAN HASIL BELAJAR MATEMATIS SISWA
}

\author{
Metrilitna Br Sembiring \\ Program Studi Pendidikan Matematika Universitas Islam Sumatera Utara \\ metrilitnasembiring@fkip.uisu.ac.id
}

\begin{abstract}
This study discusses the influence of the scientific approach to mathematical learning outcomes. The type of research used in this writing is quasi-experimental, with scientific approach data collection on students' mathematical learning outcomes. Data analysis used with Simple Regression Analysis Test. Based on the analysis obtained by the results of the study, namely: the relationship or correlation between learning approaches with student learning outcomes with regression $Y=69.222+0,101 X$, with $t_{\text {count }}=9.260$. The values for testing the data can use the Anova table $F_{\text {count }}=116,887>F_{\text {table }}$ and the significance level of $0.000<0.05$. So that it can be said that the values of the two data are different. Thus, it can be concluded that there is the influence of the scientific approach to students' mathematical learning outcomes. This shows that the learning approach has a significant effect on students' mathematical learning outcomes. The coefficient of determination is $R^{2}=0,896$ means that the contribution or influence of the santifik approach $(X)$ on the students' mathematical learning outcomes $(Y)$ is $89.6 \%>73,6 \%$. Thus, the scientific approach is better at contributing to students' mathematical learning outcomes.
\end{abstract}

Keywords: Scientific Approach, Learning Outcomes

\begin{abstract}
Abstrak. Penelitian ini membahas mengenai pengaruh pendekatan saintifik terhadap hasil belajar matematis. Jenis penelitian yang digunakan dalam penulisan ini adalah quasi eksperimen, dengan pengambilan data pendekatan saintifik terhadap hasil belajar matematis siswa. Analisis data yang digunakan dengan Uji Analisis Regresi Sederhana. Berdasarkan analisis tersebut diproleh hasil penelitian yaitu: hubungan atau korelasi antara pendekatan pembelajaran dengan hasil belajar siswa dengan regresi $Y=69.222+0,101 X$, dengan $t_{\text {hitung }}=9.260$. Adapun nilai untuk pengujian data dapat menggunakan tabel Anova $F_{\text {hitung }}=116,887>F_{\text {tabel }}$ dan tingkat signifikasi $0,000<0,05$. Sehinga dapat dikatakan bahwa nilai kedua data berbeda. Dengan demikian, dapat disimpulkan terdapat pengaruh pendekatan saintifik terhadap hasil belajar matematis siswa. Hal ini menunjukkan bahwa pendekatan pembelajaran berpengaruh secara signifikan terhadap hasil belajar matematis siswa. Koefisien determinasinya adalah $R^{2}=0,896$ artinya kontribusi atau besar pengaruh pendekatan santifik $(X)$ terhadap hasil belajar matematis siswa $(Y)$ tersebut sebesar $89.6 \%>$ $73,6 \%$. Dengan demikan, pendekatan saintifik lebih baik dalam memberikan kontribusi terhadap hasil belajar matematis siswa.
\end{abstract}

Kata kunci: Pendekatan Saintifik, Hasil Belajar

\section{PENDAHULUAN}

Pendidikan merupakan salah satu aspek dalam kehidupan yang memegang peranan yang sangat penting. Sebuah negara dapat dikatakan maju dalam teknologinya, jika pendidikan dalam negara itu baik kualitasnya. Tinggi rendahnya kualitas pendidikan pada suatu negara dipengaruhi oleh banyak faktor, antara lain dapat berasal dari siswa, pengajar, sarana prasarana, dan bisa juga karena faktor lingkungan.

Berbagai upaya telah dilakukan untuk meningkatkan mutu pendidikan di sekolah, antara lain dengan perbaikan mutu belajar mengajar. Dengan adanya perencanaan yang baik akan mendukung keberhasilan pembelajaran di kelas. Usaha perencanaan pengajaran diupayakan agar peserta didik memiliki kemampuan maksimal agar mampu memenuhi harapan baik oleh pendidik maupun peserta didik. 
Matematika merupakan salah satu mata pelajaran di sekolah yang dinilai cukup memegang peranan penting dalam membentuk siswa menjadi berkualitas, karena matematika merupakan suatu sarana berpikir untuk mengkaji sesuatu secara logis dan sistematis. Selain itu matematika juga telah dipelajari dari tingkat dasar sampai menengah atas sehingga matematika memegang peranan yang penting dalam dunia pendidikan. Oleh karena itu, perlu adanya peningkatan mutu pendidikan matematika. Salah satu yang harus diperhatikan adalah peningkatan prestasi belajar matematika siswa disekolah.Tujuan pembelajaran matematika menurut kurikulum 2004 yang dikutip Hamzah (2014:90) salah satunya adalah mengembangkan aktivitas kreatif yang melibatkan imajinasi intuisi, penemuan dengan mengembangkan pemikiran divergen orisinil, rasa ingin tahu membuat prediksi dan dugaan serta coba-coba.

Pendekatan pembelajaran merupakan strategi yang dapat memperjelas arah yang ditetapkan. Pendekatan sering kali disebut dengan kebijakan guru atau pengajar untuk mencapai tujuan pembelajaran. Tujuan pembelajaran yang dilakukan guru yaitu untuk mempermudah pemahaman siswa atas materi pembelajaran yang diberikan dengan berbeda penekanannya. Pendekatan pembelajaran diartikan sebagai cara yang ditempuh oleh guru dalam melaksanakan pembelajaran yang direncanakan agar siswa memahami konsep yang sedang dipelajari. Oleh karena itu, dibutuhkan ketepatan dalam memilih pendekatan pembelajaran.

Pembelajaran merupakan jantung dari pendidikan dalam suatu instansi pendidikan yang bersifat kompleks dan dinamis, sehingga tenaga-tenaga pendidikterutama guru perlu menerapkan strategi pembelajaran. Pembelajaran matematika yang diharapkan saat ini adalah pembelajaran yang berorientasi kepada siswa. Siswa dituntut oleh untuk aktif dan mandiri membangun sendiri pengetahuannya, guru hanya sebagai fasilitator dan pendamping.

Dari uraian di atas, menekankan bahwa yang menjadi faktor penting dalam pencapaian hasil belajar matematika yang diharapkan adalah pemilihan strategi yang efektif dan efisien oleh guru dalam menyampaikan materi pokok pelajaran khususnya pelajaran matematika. Hal tersebut sejalan dengan yang dikemukakan Jamaris (2014:177) "proses pembelajaran matematika menekankan pada keterlibatan siswa secara aktif, dengan melakukan berbagai eksplorasi yang bersifat dinamis dan melibatkan disiplin ilmu yang terkait dan menghindari proses pembelajaran yang kaku,otoriter,dan menutup diri pada kegiatan menghapal".

Untuk itu, guru hendaknya dapat menerapkan strategi mengajar yang bervariasi, sebab dengan menerapkan strategi mengajar yang bervariasi dapat membantu siswa dalam belajar dan dapat menimbulkan motivasi belajar pada siswa sehingga siswa aktif melakukan kegiatan yang diperlukan dan dapat menguasai materi pokok yang diberikan. Sebagai upaya yang dilakukan guru untuk meningkatkan hasil belajar matematika siswa disekolah dan memotivasi siswa untuk aktif belajar adalah perlu dikembangkan suatu model pembelajaran yang tepat. Salah satu model pembelajaran yang tepat dalam permasalahan ini adalah dengan menggunakan pendekatan Saintifik. Pendekatan saintifik atau lebih umum dikatakan pendekatan ilmiah merupakan pendekatan dalam implementasi kurikulum 2013. Pendekatan saintifik menjadi trending topik pada pelaksanaan kurikulum 2013. Pembelajaran pendekatan saintifik ini lebih afektif hasilnya dibandingkan dengan pembelajaran yang bersifat ceramah dan tanya jawab.

Selain itu, pendekatan saintifik dalam pembelajaran dapat mendorong siswa terlibat secara aktif dalam proses belajar. Pendekatan saintifik dalam pembelajaran memiliki komponen proses pembelajaran menurut Sani (2014), antara lain: (1). Mengamati; (2). Menanya; (3). Mencoba/mengumpulkan informasi; (4). Menalar/asosiasi; (5). Membentuk jejaringan (melakukan komunikasi). Tahapan aktifitas tersebut dapat dilakukan pada semua 
mata pelajaran, termasuk dalam pembelajaran matematika. Sasaran pembelajaran dalam kurikulum 2013 mencakup pengembangan ranah sikap (afektif), pengetahuan (kognitif), dan keterampilan (psikomotor) yang dielaborasi untuk setiap satuan pendidikan (Permendikbud Nomor 54 tahun 2013).

Pada hakikatnya, sebuah proses pembelajaran yang dilakukan di kelas-kelas bisa kita dipadankan sebagai sebuah proses ilmiah. Oleh sebab itulah, dalam Kurikulum 2013 diamanatkan tentang apa sebenarnya esensi dari pendekatan saintifik pada kegiatan pembelajaran. Ada sebuah keyakinan bahwa pendekatan ilmiah merupakan sebentuk titian emas perkembangan dan pengembangan sikap (ranah afektif), keterampilan (ranah psikomotorik), dan pengetahuan (ranah kognitif) siswa. Menurut Permendikbud Nomor 103 tahun 2014 tentang Pembelajaran Pada Pendidikan Dasar dan Pendidikan Menengah, ada lima pengalaman belajar dengan pendekatan saintifik yaitu mengamati, menanya, mencoba, mengasosiasi dan mengkomunikasikan (Tim Penyusun, 2014).

\section{METODE}

Penelitian ini dilaksanakan pada materi sistem persamaan linier dua variabel. Analisis data yang digunakan dalam penelitian ini yaitu analisis kuantitatif. Analisis kuantitatif digunakan untuk menganalisis hasil belajar matematis siswa. Dalam melakukan analisis terhadap besar pengaruh pendekatan saintifik terhadap hasil belajar matematis siswa maka terlebih dahulu harus diketahui besar koefisien korelasi sehingga besar pengaruh atau kontribusi dapat ditentukan. Koefisien korelasi adalah bilangan yang menyatakan kekuatan dua hubungan antara dua variabel atau lebih atau juga dapat menentukan arah dari ke dua variabel (Siregar, 2014:251). Nilai koefisien korelasi berada antara +1 dan -1 , sedangkan untuk arah dinyatakan dalam bentuk (+) dan (-).

Untuk menghitung nilai koefisien korelasi ini menggunakan analisis regresi linear sederhana. Kegunaan regresi dalam penelitian salah satunya adalah untuk memprediksi variabel terikat (Y) dengan variabel bebas $(\mathrm{X})$ diketahui. Regresi sederhana dapat dianalisis karena didasari oleh hubungan fungsional atau hubungan sebab akibat variabel bebas (X) terhadap variabel terikat $(Y)$. Adapun rumus regresi linear sederhana sebagai berikut:

$$
Y^{\prime}=a+b X
$$

Keterangan:

$$
\begin{aligned}
& Y^{\prime}: \text { nilai yang diprediksikan } \\
& a: \text { konstan atau bila harga } \mathrm{X}=0 \\
& b: \text { koefisien regresi } \\
& X: \text { nilai variabel independen }
\end{aligned}
$$

Interpretasi koefisien korelasi menurut Sugiyono (2010:184) ditunjukkan pada Tabel berikut ini:

Tabel 1. Tingkat Korelasi Dan Kekuatan Hubungan

\begin{tabular}{cc}
\hline Interval korelasi & Tingkat hubungan \\
\hline $0,00-0,199$ & Sangat rendah \\
\hline $0,20-0,399$ & Rendah \\
\hline $0,40-0,599$ & Sedang \\
\hline $0,60-0,799$ & Kuat \\
\hline $0,80-1,000$ & Sangat kuat \\
\hline
\end{tabular}

Hipotesis statistik yang diujikan dalam penelitian ini adalah sebagai berikut: Hipotesis

$$
\begin{aligned}
& H_{o}: \mu_{k p m(\text { Pendekatan saintifik })}=\mu_{k p m(P L)} \\
& H_{o}: \mu_{k p m(\text { Pendekatan saintifik })}>\mu_{k p m(P L)}
\end{aligned}
$$


Keterangan:

$$
\begin{aligned}
\mu_{\text {kpm(Pendekatan Saintifik) }:} & \text { rata-rata hasil belajar matematis siswa pada } \\
& \text { pembelajaran pendekatan saintifik } \\
\mu_{\text {kpm(Pembelajaran Langsung) }} & \begin{array}{l}
\text { rata-rata hasil belajar matematis siswa pada } \\
\text { pembelajaran langsung }
\end{array}
\end{aligned}
$$

\section{Hasil dan Pembahasan}

Hasil Postest Kemampuan hasil belajar matematis siswa

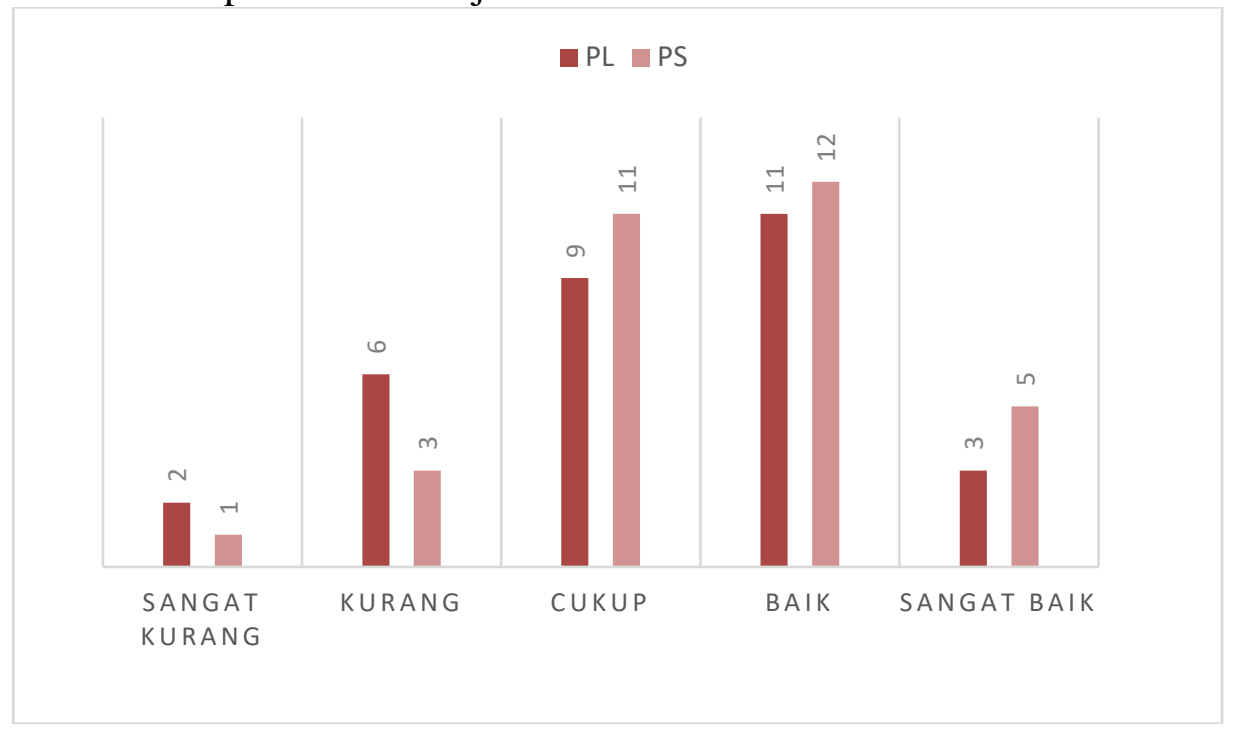

Gambar 1. Hasil Kemampuan Hasil Belajar Siswa

Dari Gambar 1 terlihat jelas pada masing-masing kriteria, pendekatan pembelajaran terlihat sangat baik dalam meningkatkan kemampuan hasil belajar matematis. Ini terlihat dari banyaknya siswa yang mendapatkan kategori baik dan sangat baik pada kelas yang menggunakan pendekatan saintifik lebih banyak dibandingkan kelas yang menggunakan pembelajaran langsung.

Hal ini menunjukkan bahwa pendekatan saintifik mampu meningkatkan hasil belajar masalah matematis siswa. Dengan demikian, secara klasikal kelas eksperimen telah memenuhi aspek peningkatan belajar sedangkan kelas kontrol belum memenuhinya. Ini mengindikasikan bahwa pendekatan pembelajaran baik diterapkan dalam pembelajaran matematika khususnya pada pokok bahasan materi sistem persamaan linear dua variabel untuk meningkatkan hasil belajar matematis siswa.

Tabel 2. Hasil Uji Normalitas Tes Hasil Belajar Siswa (Pretest)

One-Sample Kolmogorov-Smirnov Test

\begin{tabular}{llrr}
\hline $\mathrm{N}$ & & Eksperimen & \multicolumn{1}{c}{ Kontrol } \\
\hline \multirow{2}{*}{ Normal Parameters ${ }^{\mathrm{a}, \mathrm{b}}$} & Mean & 32 & 31 \\
& Std. Deviation & 60.63 & 49.03 \\
& Absolute & 16.252 & 19.724 \\
Most Extreme Differences & Positive & .208 & .146 \\
& Negative & .099 & .126 \\
Kolmogorov-Smirnov Z & & -.208 & -.146 \\
Asymp. Sig. (2-tailed) & & 1.179 & .811 \\
\hline
\end{tabular}

a. Test distribution is Normal.

b. Calculated from data. 
Tabel 3. Hasil Uji Normalitas Tes Hasil Belajar Siswa (Postest)

One-Sample Kolmogorov-Smirnov Test

\begin{tabular}{llrr}
\hline & & Eksperimen & Kontrol \\
\hline $\mathrm{N}$ & & 32 & 31 \\
Normal Parameters & Mean & 84.94 & 66.29 \\
& Std. Deviation & 8.254 & 17.605 \\
& Absolute & .159 & .173 \\
Most Extreme Differences & Positive & .114 & .094 \\
& Negative & -.159 & -.173 \\
Kolmogorov-Smirnov Z & & .901 & .966 \\
Asymp. Sig. (2-tailed) & & .391 & .308 \\
\hline a. Test distribution is Normal. & & \\
b. Calculated from data. & & &
\end{tabular}

Uji homogenitas adalah pengujian sama tidaknya variabel-variabel dengan dua distribusi atau lebih. Pengujian homogenitas ini menggunakan uji varians dua buah peubah bebas. Pengujian homogenitas dalam penelitian ini diambil sampel di kelas eksperimen sebanyak 32 orang siswa dan di kelas kontrol sebanyak 31 siswa. Sementara sebelumnya telah dihitung data pretest dan postest hasil belajar berdistribusi normal. Namun di sini yang akan diuji adalah keseluruhan aspek sebagai syarat untuk menggunakan analisis regresi.

Varians pretest kemampuan hasil belajar keseluruhan aspek di kelas eksperimen $\left(S_{E}^{2}\right)=16.252$ dan varians pretes kemampuan hasil belajar di kelas kontrol $\left(S_{K}^{2}\right)=$ 19.724. Dapat diperoleh $F_{\text {hitung }}=\frac{S_{\text {besar }}^{2}}{S_{\text {kecil }}^{2}}=\frac{19.724}{16.252}=1,213$ dan $F_{\text {tabel }}=4,17$ dan taraf signifikan $(\alpha)=5 \%$. Jika $F_{\text {hitung }}<F_{\text {tabel }}$, maka Ho diterima artinya data pretes kemampuan hasil belajar keseluruhan aspek homogen. Sementara hasil perhitungan homogenitas untuk pretes dengan menggunakan SPSS 20 secara ringkas dideskripsikan, pada tabel berikut:

Tabel 4. Hasil Uji Homogenitas Tes Kemampuan Hasil Belajar (Pretest)

Test of Homogeneity of Variances

\begin{tabular}{rrrr}
\hline Levene Statistic & \multicolumn{1}{c}{ df1 } & df2 & Sig. \\
\hline 4.059 & 7 & 21 & .006 \\
\hline
\end{tabular}

Dari Tabel 4 terlihat signifikasi (mean) pretest 0,006 $>0,05$. Dengan demikian, dapat diartikan bahwa kelas eksperimen dan kelas kontrol untuk tes pretes kemampuan hasil belajar memiliki varians yang sama.

Varians postes kemampuan hasil belajar keseluruhan aspek di kelas eksperimen $\left(S_{E}^{2}\right)=8.254$ dan varians postes kemampuan hasil belajar di kelas kontrol $\left(S_{K}^{2}\right)=17.605$. Dapat diperoleh $F_{\text {hitung }}=\frac{S_{\text {besar }}^{2}}{S_{\text {kecil }}^{2}}=\frac{17.605}{8.254}=2,132$ dan $F_{\text {tabel }}=4,16$ dan taraf signifikan $(\alpha)=5 \%$. Jika $F_{\text {hitung }}<F_{\text {tabel }}$ maka, Ho diterima artinya data postes kemampuan hasil belajar keseluruhan aspek homogen. Sementara hasil perhitungan homogenitas untuk postes secara ringkas dideskripsikan pada Tabel berikut.

Tabel 5. Hasil Uji Homogenitas Tes Kemampuan Hasil Belajar (Postest)

Test of Homogeneity of Variances

\begin{tabular}{cccc}
\hline Levene Statistic & $\mathrm{df} 1$ & $\mathrm{df2}$ & Sig. \\
\hline 1.037 & 7 & 21 & .436 \\
\hline
\end{tabular}

Dari Tabel 5 terlihat signifikasi (mean) postes 0,436 >0,05. Dengan demikian, dapat diartikan bahwa kelas eksperimen dan kelas kontrol untuk tes postest kemampuan hasil belajar memiliki varians yang sama. 


\section{Pengujian Hipotesis Kemampuan Hasil Belajar Matematis Siswa}

Selanjutnya uji hipotesis ada tidaknya pengaruh pendekatan saintifik terhadap kemampuan hasil belajar matematis siswa dapat dilakukan karena persyaratan uji telah terpenuhi. Hipotesis yang diuji adalah:

$$
\begin{aligned}
& H_{o}: \mu_{k p m(\text { Pendekatan saintifik })}=\mu_{k p m(P L)} \\
& H_{o}: \mu_{k p m(\text { Pendekatan saintifik })}>\mu_{k p m(P L)}
\end{aligned}
$$

Analisis Pengaruh Model Pembelajaran Pendekatan Saintifik Terhadap Kemampuan Hasil Belajar Matematis Siswa

Untuk mengetahui atau memprediksi besar pengaruh pendekatan saintifik terhadap kemampuan hasil belajar matematis dianalisis menggunakan analisis regresi linear sederhana. Adapun rangkuman hasil analisis regresi linear sederhana menggunakan SPSS 20, pada Tabel 6 berikut:

Tabel 6. Analisis Regresi Linear Sederhana Pada Kelas Eksperimen Model Summary

\begin{tabular}{rrrrr}
\hline Model & $\mathrm{R}$ & R Square & $\begin{array}{c}\text { Adjusted R } \\
\text { Square }\end{array}$ & Std. Error of the Estimate \\
\hline 1 & $.982^{\mathrm{a}}$ & .896 & .879 & 16.498 \\
\hline
\end{tabular}

a. Predictors: (Constant), PS

b. Dependent Variabel: KPM

ANOVA $^{a}$

\begin{tabular}{|lrrrrr}
\hline \multicolumn{1}{c}{ Model } & Sum of Squares & df & Mean & S & Sig. \\
\hline Regression & 21.634 & 1 & 21.634 & 116,887 & $.780^{\mathrm{b}}$ \\
Residual & 8165.866 & 30 & 272.196 & & \\
Total & 8187.500 & 31 & & & \\
\hline
\end{tabular}

a. Dependent Variable: KPM

b. Predictors: (Constant), PS

Coefficients $^{a}$

\begin{tabular}{lrrrrrr}
\hline \multirow{2}{*}{ Model } & \multicolumn{2}{c}{ Unstandardized Coefficients } & \multicolumn{2}{c}{$\begin{array}{c}\text { Standardized } \\
\text { Coefficients }\end{array}$} & \multirow{2}{*}{ S } & \multicolumn{2}{c}{ Sig. } \\
\cline { 2 - 5 } & \multicolumn{1}{c}{ B } & Std. Error & Beta & & \\
\hline (Constant) & 69.222 & 30.633 & & 9.260 & .041 \\
PS & .101 & .359 & .051 & .282 & .000 \\
\hline
\end{tabular}

a. Dependent Variable: KPM

Dari Tabel 6 dapat dianalisis bahwa hubungan atau korelasi antara pendekatan pembelajaran dengan peningkatan kemampuan hasil belajar dengan regresi $Y=69.222+$ $0,101 X$, dengan $t_{\text {hitung }}=9.260$ dan tingkat signifikasi 0,000 lebih kecil dari 0,05. Hal ini menunjukkan bahwa pendekatan pembelajaran berpengaruh secara signifikan terhadap kemampuan hasil belajar matematis siswa. Koefisien determinasinya adalah $R^{2}=0,896$ artinya kontribusi atau besar pengaruh pendekatan santifik $(\mathrm{X})$ terhadap kemampuan hasil belajar matematis siswa (Y) tersebut sebesar $89.6 \%$.

\section{Analisis Pengaruh Model Pembelajaran Langsung Terhadap Kemampuan Hasil Belajar}

Untuk mengetahui atau memprediksi besar pengaruh model pembelajaran langsung terhadap kemampuan hasil belajar matematis dianalisis menggunakan analisis regresi linear sederhana. Adapun rangkuman hasil analisis regresi linear sederhana menggunakan SPSS 20, pada Tabel 7 berikut: 
Pengaruh pendekatan saintifik terhadap kemampuan...

Tabel 7. Analisis Regresi Linear Sederhana Pada Kelas Kontrol

\begin{tabular}{lrrrr}
\hline Model & $\mathrm{R}$ & $\mathrm{R}$ Square & $\begin{array}{c}\text { Adjusted R } \\
\text { Square }\end{array}$ & Std. Error of the Estimate \\
\hline 1 & $.858^{\mathrm{a}}$ & .736 & .727 & 10.302 \\
\hline $\begin{array}{l}\text { a. Predictors: (Constant), PS } \\
\text { b. Dependent Variabel: KPM }\end{array}$
\end{tabular}

\begin{tabular}{|c|c|c|c|c|c|}
\hline \multicolumn{6}{|c|}{ ANOVA $^{a}$} \\
\hline Model & Sum of Squares & $d f$ & $\begin{array}{c}\text { Mean } \\
\text { Square }\end{array}$ & $\mathrm{F}$ & Sig. \\
\hline Regression & 8592.945 & 1 & 8592.945 & 80.960 & $.000^{\mathrm{b}}$ \\
\hline Residual & 3078.023 & 29 & 106.139 & & \\
\hline Total & 11670.968 & 30 & & & \\
\hline
\end{tabular}

\begin{tabular}{|c|c|c|c|c|c|}
\hline \multicolumn{6}{|c|}{ Coefficients $^{a}$} \\
\hline \multirow{2}{*}{ Model } & \multicolumn{2}{|c|}{ Unstandardized Coefficients } & $\begin{array}{c}\text { Standardized } \\
\text { Coefficients }\end{array}$ & \multirow{2}{*}{$\mathrm{t}$} & \multirow{2}{*}{ Sig. } \\
\hline & $\mathrm{B}$ & Std. Error & Beta & & \\
\hline (Constant) & 4.694 & 7.320 & & .007 & .054 \\
\hline PS & .961 & .107 & .858 & 7.998 & .000 \\
\hline
\end{tabular}

Dari Tabel 7 dapat dianalisis bahwa hubungan atau korelasi antara pendekatan saintifik dengan peningkatan kemampuan hasil belajar dengan regresi $Y=4.694+$ $0,961 X$, dengan $t_{\text {hitung }}=7.998$ dan tingkat signifikasi 0,000 lebih kecil dari 0,005. Hal ini menunjukkan bahwa pembelajaran langsung berpengaruh secara signifikan terhadap kemampuan pemecahan masalah matematis siswa. Koefisien determinasinya adalah $R^{2}=$ 0,736 artinya kontribusi atau besar pengaruh model pembelajaran langsung $(\mathrm{X})$ terhadap kemampuan hasil belajar matematis siswa (Y) tersebut sebesar $73.6 \%$.

\section{KESIMPULAN}

Berdasarkan hasil analisis data dapat disimpulkan terdapat pengaruh pendekatan saintifik terhadap hasil belajar matematis siswa. Hal ini menunjukkan bahwa pendekatan pembelajaran berpengaruh secara signifikan terhadap hasil belajar matematis siswa. Koefisien determinasinya adalah $R^{2}=0,896$ artinya kontribusi atau besar pengaruh pendekatan santifik $(X)$ terhadap hasil belajar matematis siswa $(Y)$ tersebut sebesar 89.6\% $>73,6 \%$. Dengan demikan, pendekatan saintifik lebih baik dalam memberikan kontribusi terhadap hasil belajar matematis siswa. Berdasarkan hasil penelitian yang telah disimpulkan di atas, dalam upaya meningkatkan mutu pendidikan perlu dikemukakan beberapa saran sebagai berikut: 1) Diharapkan guru dapat menerapkan Pendekatan Saintifik untuk meningkatkan kemampuan hasil belajar matematika dalam pembelajaran matematika pada materi lain; 2) Sebaiknya pendekatan Saintifik dapat dijadikan suatu alternatif yang dapat mengoptimalkan hasil belajar siswa terlebih khusus kemampuan hasil belajar dalam materi sistem persamaan linear dua variabel. Pendekatan saintifik yang dihasilkan dapat dijadikan bandingan bagi guru dalam mengembangkan perangkat pembelajaran; dan 3) Hendaknya fasilitas kemampuan siswa dalam memecahkan masalah dapat menggunakan kemajuan teknologi berupa penggunaan komputerisasi.

\section{DAFTAR PUSTAKA}

Abdurrahman, M. 2012. Anak Berkesulitan Belajar: Teori, Diagnosis dan Remediasinya. Jakarta: Rineka Cipta. 
Amir, Z. \& Risnawati. 2016. Psikolog pembelajaran matematika. Yogyakarta: Asmaja Pressindo.

Arikunto, S. 2013. Dasar-Dasar Evaluasi Pendidikan. Jakarta: Bumi Aksara.

Arikunto, S. 2013. Prosedur Penelitian. Jakarta: Rineka Cipta.

Asta, I. K. R., Agunng, A. A. G., \& Widiana, I. W. 2015. Pengaruh pendekatan saintifik dan kemampuan berpikir kritis terhadap hasil belajar IPA. EJournal PGSD Universitas Pendidikan Ganesha. 3(1): 1-10.

Chairani, Z. dkk. 2015. Perilaku Metakognisi Siswa dalam Pemecahan Masalah Matematika. Mat Didactic: Jurnal Pendidikan Matematika. 3(1):200-210.

Dimyanti \& Mudjono, 2013. Belajar dan Pembelajaran. Jakarta: PT. Rineka Cipta.

Djamarah, \& Zain A. 2000. Strategi Belajar Mengajar. Jakarta. Rineka Cipta.

Erny. dkk. 2017. Pengaruh Pendekatan Saintifik Pada Pembelajaran Matematika Terhadap Kemampuan Pemecahan Masalah dan Kemampuan Berfikir Tingkat Tinggi Siswa Kelas X IPA SMA Negeri 1 Kepahing. Jurnal Pendidikan Matematika Raflesia. 2(1). Hartono, Y. 2014. Matematika Strategi Pemecahan Masalah. Yogyakarta: Graha Ilmu. Hasratuddin. 2015. Mengapa Harus Belajar Matematika?. Medan: Perdana Publishing. Mahanani, L. G. dkk. 2016. Kemampuan Pemecahan Masalah Matematika Aljabar Berbasis Timss Pada Siswa SMP Kelas VII. Prosiding Seminar Nasional Pendidikan Matematika 2016. 1-9.

Sudjana, N. 1999. Penilaian Hasil proses Belajar mengajar. Bandung; Remaja Rosdakarya. 